\title{
The growth-inhibitory effects of tomatoes digested in vitro in colon adenocarcinoma cells occur through down regulation of cyclin D1, Bcl-2 and Bcl-xL
}

\author{
Paola Palozza ${ }^{1 *}$, Simona Serini ${ }^{1}$, Alma Boninsegna ${ }^{1}$, Diana Bellovino ${ }^{2}$, Massimo Lucarini $^{2}$, \\ Giovanni Monastra ${ }^{2}$ and Sancia Gaetani ${ }^{2}$ \\ ${ }^{1}$ Institute of General Pathology, Catholic University School of Medicine, Largo F. Vito, 1 00168 Rome, Italy \\ ${ }^{2}$ National Research Institute on Food and Nutrition, Via Ardeatina 546, 00178 Rome, Italy \\ (Received 8 December 2006 - Revised 29 March 2007 - Accepted 30 March 2007)
}

In the present study, we utilised an in vitro digestion procedure to deliver molecules contained in tomatoes to cultured cells and to analyse potential mechanisms underlying the antitumoural effects of tomatoes reported in the literature. Ripe tomatoes underwent in vitro simulated digestion and the aqueous fraction obtained was delivered to HT-29 and HCT-116 colon adenocarcinoma cells. The amount of lycopene released during digestion and transferred to the aqueous fraction during digestion was 10 -fold lower than that present in tomato homogenate before digestion. The carotenoid was accumulated by colon adenocarcinoma cells in a dose-dependent manner after the addition of tomato digestate (20-100 $\mathrm{ml} / \mathrm{l})$ for $24 \mathrm{~h}$. Tomato digestate inhibited the growth of HT-29 and HCT-116 cells in a dose-dependent manner. Growth inhibition resulted from an arrest of cell cycle progression at the G0/G1 phase and by apoptosis induction. A down regulation of cyclin D1, Bcl-2 and Bcl-xL expression was also observed, without apparent changes in p53, p21, p27 and Bax. In conclusion, the present data demonstrate that the in vitro digestion procedure represents a useful approach to supply tomato to colon cultured cells. Moreover, we have shown that tomato digestate is able to inhibit the growth of colon cancer cells by modulating the expression of regulators of the cell cycle and apoptosis.

Tomatoes: In vitro digestion: Cell cycle: Apoptosis: Colon cancer cells

Epidemiological and clinical studies have suggested health benefits of tomatoes and tomato-based food products ${ }^{1,2}$. Dietary intake of tomato and tomato products has been shown to be associated with a decreased risk of $\mathrm{CVD}^{3,4}$ and of certain cancers ${ }^{5}$, including those of the digestive tract ${ }^{6}$, prostate ${ }^{7,8}$ and pancreas ${ }^{9}$.

Tomato and tomato-based food products contain a large variety of micronutrients (pro-vitamin $\mathrm{A}$, vitamin $\mathrm{C}$, folate and $\mathrm{K}$ ) and microconstituents, including polyphenols and non-pro-vitamin A carotenoids ${ }^{10-12}$. Lycopene is the most representative carotenoid in ripe tomatoes ${ }^{13}$ and it is responsible for the deep-red colour of tomatoes and tomato-based foods ${ }^{14}$. It represents approximately 80 to $90 \%$ of the pigments present. Most of this carotenoid is consumed from tomatoes and tomato products, such as juice, pasta and sauce $^{14}$. Other carotenoids are also present in tomatoes, such as phytoene, phytofluene and, in minor amounts, $\alpha$-carotene, $\beta$-carotene, lutein and cryptoxanthin ${ }^{13}$.

In recent years there have been suggestions that lycopene may be responsible for the health benefits of tomato-based food products. In particular, an important study was conducted $^{7}$ in which a significant number of men, supplemented with fresh tomatoes, tomato sauce and pizza, were followed from 1986 to 1992 . This study clearly showed that the intake of lycopene but not that of other carotenoids, including $\alpha$-carotene, $\beta$-carotene, lutein, and $\beta$-cryptoxanthinin, in tomatoes was associated with a lower risk for prostate cancers. Moreover, serum and tissue lycopene levels have been inversely related to the risk of prostate cancers ${ }^{15}$.

Although several in vitro studies have been performed to elucidate possible mechanisms underlying the beneficial effects of lycopene on health ${ }^{16}$, experimental studies on carotenoid functions in cell-culture models are limited by the absence of an adequate method of solubilising lycopene, which could lead to misinterpretation of the physiological significance of the observed phenomena. In fact, the high hydrophobicity of this carotenoid ${ }^{13}$ makes it very insoluble in aqueous systems and therefore poorly available for cell cultures. In most in vitro studies, lycopene was provided to cultured cells as a tetrahydrofuran solution. Although it has been reported that tetrahydrofuran can easily solubilise lycopene $^{17}$, it does not contribute to its stability in solution ${ }^{18}$. Moreover, it can determine non-specific uptake of the carotenoid and it can cause problems of toxicity.

Therefore, the main aims of the present study were: (1) to define and utilise a physiological approach consisting of an in vitro tomato digestion, to deliver lycopene-containing tomatoes to colon cultured cells; (2) to analyse antitumoural effects 
of the aqueous fraction of tomato digestate. HT-29 and HCT116 cells were used as the model system, since they are colon cancer cells, still exhibiting many morphological and biochemical similarities with intestinal cells. Colon carcinoma cell lines have been reported to accumulate carotenoids ${ }^{19}$.

\section{Materials and methods}

Preparation of tomato samples and in vitro simulated digestion

All manipulations with tomato samples were performed under subdued lighting and in amber glass bottles to minimise the destruction of carotenoids. Samples of $60 \mathrm{mg}$ lyophilised ripe tomatoes (Lycopersicon esculentum Mill. cv Red Setter), corresponding to $1 \mathrm{~g}$ fresh tomato, were mixed with $1.8 \mathrm{ml}$ saline (140 mM-NaCl, $5 \mathrm{~mm}-\mathrm{KCl}, 150 \mu \mathrm{M}$-butylated hydroxytoluene in tetrahydrofuran) and hand-homogenised in a Teflon-glass Potter homogeniser (Thomas, Philadelphia, USA). In vitro simulated digestion was performed according to Garrett et al. ${ }^{20}$ with modifications. Briefly, after homogenisation, samples were acidified to $\mathrm{pH} 2.0$ with $1 \mathrm{M}-\mathrm{HCl}$ before the addition of $50 \mu \mathrm{l}$ pepsin, from porcine stomach mucosa $(0 \cdot 2 \mathrm{~g}$ pepsin in $5 \mathrm{ml}$ of $0.1 \mathrm{M}-\mathrm{HCl})$, and samples were incubated in a shaking water-bath for $60 \mathrm{~min}$ at $37^{\circ} \mathrm{C}$. After gastric digestion, the $\mathrm{pH}$ was raised to 6.9 with $1 \mathrm{M}$ $\mathrm{NaHCO}_{3}$. Intestinal digestion was simulated by the addition of $200 \mu \mathrm{l}$ pancreatin-bile solution from porcine pancreas $(0.45 \mathrm{~g}$ porcine bile extract and $0.075 \mathrm{~g}$ pancreatin in $37.5 \mathrm{ml}$ of $0.1 \mathrm{M}-$ $\mathrm{NaHCO}_{3}$ ) and incubated in a shaking water-bath at $37^{\circ} \mathrm{C}$ for $120 \mathrm{~min}$. The $\mathrm{pH}$ of the samples was then adjusted to $7 \cdot 5$.

The heat-treated tomatoes were obtained by $15 \mathrm{~min}$ incubation in a boiling water-bath before gastric digestion.

Samples were centrifuged at $12000 \mathrm{rpm}$ for $30 \mathrm{~min}$ at $4^{\circ} \mathrm{C}$ in a Sorvall SS-34 angle rotor (Du Point Instruments, Toronto, Canada), and supernatant fractions collected and stored at $-80^{\circ} \mathrm{C}$.

The amount of lycopene in the different tomato preparations was expressed in $\mu \mathrm{g} / \mathrm{g}$ fresh weight (60 mg lyophilised tomato correspond to $1 \mathrm{~g}$ fresh tomato).

\section{Cell culture}

HT-29 human colon adenocarcinoma cells (American Type Culture Collection, Rockville, MD, USA) were grown in modified Eagle's medium. HCT-116 colon carcinoma cells were cultured in McCoy's 5a. Cells were maintained in log phase by seeding them twice per week at the density of $3 \times 10^{5}$ cells $/ \mathrm{ml}$ at $37^{\circ} \mathrm{C}$ under $5 \% \mathrm{CO}_{2}$-air atmosphere. The medium was supplemented with $10 \%(\mathrm{v} / \mathrm{v})$ fetal calf serum (Flow Laboratories, Irvine, Ayrshire, UK) and $2 \mathrm{~mm}$-glutamine. The medium was not further replaced throughout the experiments. Experiments were routinely carried out on triplicate cultures. After the incubation, cells were harvested and quadruplicate haemocytometer counts were performed. The trypan blue dye exclusion method was used to evaluate the percentage of viable cells.

\section{Cell growth-inhibition assay}

Curves of cell growth inhibition were determined for both HT-29 and HCT-116 cells. Serial dilution of tomato digestate with culture medium was used $(1: 10,1: 20 ; 1: 50)$. Cells were seeded in twenty-four-well plates with $3 \times 10^{4}$ cells/well and divided into control and treatment groups. Cells were maintained for $24 \mathrm{~h}$ before any treatment to facilitate their adhesion on the well. The control group consisted of cells treated with the same amount of digestion mixture, as indicated earlier, diluted with culture medium $(1: 10,1: 20 ; 1: 50)$ and of cells without any treatment. Since no differences in terms of viability, cell cycle, caspase activity and cell-cycle-related proteins were found between the two groups, untreated cells are referred to as control cells. For each treatment, cells from four wells were used. At the time indicated $(24 \mathrm{~h})$, cells were removed from the wells, stained with trypan blue and counted under a microscope for viable and dead cells.

\section{Cell cycle analysis}

Cell cycle distribution was analysed by flow cytometry, as previously described ${ }^{21}$. Samples of $10^{6}$ cells were harvested by centrifugation, washed in PBS and fixed with ice-cold $70 \%$ ethanol. The cells were incubated at $4^{\circ} \mathrm{C}$ for $30 \mathrm{~min}$ and then centrifuged at $2500 \mathrm{~g}$ for $10 \mathrm{~min}$. The pellet was resuspended in $0.5 \mathrm{ml}$ PBS and $0.5 \mathrm{ml}$ DNA-Prep stain (Coulter Reagents, Miami, FL, USA), containing RNAse (1 g/l) and propidium iodide $(50 \mathrm{~g} / \mathrm{l})$. All samples were incubated for $30 \mathrm{~min}$ in the dark at $4^{\circ} \mathrm{C}$. The DNA content of cells stained with propidium iodide was measured with a FACS instrument (EPICS XL-MCL Flow Cytometer; Coulter Electronics, FL, USA), by using Multicycle AV software.

\section{Caspase-3 activity assay}

The activity of caspase- 3 was determined as indicated ${ }^{22}$. Briefly, after a $24 \mathrm{~h}$ treatment, cells $\left(2 \times 10^{6}\right)$ were lysed in $50 \mathrm{~mm}$-tri(hydroxymethyl)-aminomethane- $\mathrm{HCl}$ buffer $(\mathrm{pH}$ 7.5) containing $0.5 \mathrm{~mm}$-EDTA, $0.5 \%$ IGEPAL $^{\circledR}$ CA-630 (Sigma Aldrich, St. Louis, MO, USA) and $150 \mathrm{~mm}-\mathrm{NaCl}$, and cell lysate was incubated with $50 \mu \mathrm{M}$-fluorogenic substrate, coumarin (Alexis Biochemicals, San Diego, CA, USA), in a reaction buffer (10 mM-HEPES ( $\mathrm{pH} 7.5)$ containing $50 \mathrm{~mm}-\mathrm{NaCl}$ and $2.5 \mathrm{~mm}$-dithiothreitol) for $120 \mathrm{~min}$ at $37^{\circ} \mathrm{C}$. The release of coumarin was measured with excitation at $380 \mathrm{~nm}$ and emission at $460 \mathrm{~nm}$ using a fluorescence spectrophotometer.

Western blot analysis of cyclin D1, p53, p21 WAF-1/CIP-1,$p 27$, Bax, Bcl-2 and Bcl-xL expression

Cells $\left(10 \times 10^{6}\right)$ were harvested, washed once with ice-cold PBS and gently lysed for $30 \mathrm{~min}$ in ice-cold lysis buffer ( $1 \mathrm{~mm}^{-\mathrm{MgCl}_{2}}, 350 \mathrm{~mm}-\mathrm{NaCl}, 20 \mathrm{~mm}-\mathrm{HEPES}, 0.5 \mathrm{~mm}$-EDTA, $0.1 \mathrm{~mm}$-ethylene glycol-bis( $\beta$-aminoethylether)- $N, N, N^{\prime}, N^{\prime}$ tetra-acetic acid, $1 \mathrm{mM}$-dithiothreitol, $1 \mathrm{mM}-\mathrm{Na}_{4} \mathrm{P}_{2} \mathrm{O}_{7}, 1 \mathrm{mM}$ phenylmethylsulfonyl fluoride, $1 \mathrm{mM}$-aprotinin, $1.5 \mathrm{~mm}$-leupeptin, $1 \mathrm{~mm}-\mathrm{Na}_{3} \mathrm{VO}_{4}, 20 \%$ glycerol and $1 \%$ Nonidet $\mathrm{P} 40$ ). Cell lysates were centrifuged for $10 \mathrm{~min}$ at $4^{\circ} \mathrm{C}(10000 \mathrm{~g})$ to obtain the supernatant fractions, which were used for Western blot analysis. The anti-cyclin D1 (clone 72-13G, catalogue no. SC-450), anti-p21 WAF-1/CIP-1 (clone F-5, catalogue no. 6246), anti-p27 (clone N-20, catalogue no. SC-527), anti-Bax (clone P-19, catalogue no. SC-526) and anti-Bcl-xL S/1 (clone L-19, catalogue no. SC-1041) monoclonal antibodies were purchased from Santa Cruz Biotechnology (Santa Cruz, 
CA, USA). The anti-p53 (clone DO-1, catalogue no. SC-126) and the anti-Bcl-2 (clone Bcl-2/100/D5) monoclonal antibodies were purchased from YLEM (Rome, Italy). The blots were washed with PBS and exposed to horseradish peroxidase-labelled secondary antibodies (Amersham Pharmacia Biotech, Arlington Heights, IL, USA) for $45 \mathrm{~min}$ at room temperature. The immunocomplexes were visualised by the enhanced chemiluminescence detection system (ECL ${ }^{\mathrm{TM}}$ Western blotting Analysis System; Amersham, Chalfont, Bucks, UK) and quantified by densitometric scanning.

\section{Extraction and analysis of lycopene}

Lycopene was extracted from fresh (2 g) and lyophilised (120 mg reconstituted in $2 \mathrm{ml}$ saline solution) tomato digestates and from cells $\left(10 \times 10^{6}\right)$ as described ${ }^{23,24}$. Cell pellets were resuspendend in $6 \mathrm{M}$-guanidine hydrochloride in $20 \mathrm{~mm}$-potassium phosphate $(\mathrm{pH} \mathrm{2.3)}$ and then extracted twice with hexane $(0.5 \mathrm{mg}$ butylated hydroxytoluene/1). Hexane layers were combined and evaporated to dryness under a stream of $\mathrm{N}_{2}$. The residue was redissolved in $200 \mu \mathrm{l}$ methanol-tetrahydrofuran (90:10, v/v, $0.5 \mathrm{mg}$ butylated hydroxytoluene/l) and $20 \mu \mathrm{l}$ was injected into an HPLC system. The carotenoid was analysed by HPLC, as described ${ }^{25}$. Chromatographic analyses were performed by the HPLC system provided with a Waters 600 pump, a C18 Inertsil ODS-80 A reversed-phase column $(5 \mu \mathrm{m}, 250 \times 4.6 \mathrm{~mm}$; GL Sciences Inc., Torrance, CA, USA) and a photodiode array detector (Waters 996). The mobile phase was constituted by a mixture of $\mathrm{CH}_{3} \mathrm{CN}-$ $\mathrm{CH}_{2} \mathrm{Cl}_{2}-\mathrm{CH}_{3} \mathrm{OH}(70 / 20 / 10$, by vol.).

\section{Statistical analysis}

Three separate cultures per treatment were utilised for analysis in each experiment. Values are presented as mean values with their standard errors. One-way ANOVA was adopted to assess any differences among the treatments or the concentrations. When significant values were found $(P<0 \cdot 05)$, post hoc comparisons of means were made using Fisher's test. Differences were analysed using Minitab Software (Minitab, Inc., State College, PA, USA).

\section{Results}

Total lycopene content in fresh tomatoes, in lyophilised tomatoes and in digestate is shown in Table 1. During the dehydration process, lycopene content remained essentially

Table 1. Lycopene content in fresh, lyophilised and digested tomatoes (Mean values with their standard errors of three different determinations)

\begin{tabular}{lrr}
\hline & \multicolumn{2}{c}{$\begin{array}{c}\text { Lycopene content } \\
\left(\mu \mathrm{g} / \mathrm{g} \text { fresh weight }{ }^{*}\right)\end{array}$} \\
\cline { 2 - 3 } & Mean & SEM \\
\hline Fresh tomato & $89.9^{\mathrm{b}}$ & $7 \cdot 1$ \\
Lyophilised tomato & $88 \cdot 5^{\mathrm{b}}$ & $6 \cdot 9$ \\
Digestate & $8 \cdot 2^{\mathrm{a}}$ & $0 \cdot 6$ \\
\hline a,b Mean values within a column with unlike superscript letters were significantly \\
different $(P<0 \cdot 05)$ (Fisher's test). & \\
${ }^{*} 60$ mg Lyophilised tomato correspond to $1 \mathrm{~g}$ fresh tomato.
\end{tabular}

constant, the amount of this carotenoid in fresh tomatoes being quite similar to that found in dehydrated ones. The amount of lycopene transferred to the aqueous fraction during the digestion procedure was 8.2 (SEM 0.6) $\mu \mathrm{g} / \mathrm{g}$ fresh weight, which corresponds to roughly one-tenth of the amount of lycopene contained in the fresh tomatoes. Lycopene was not detected in the aqueous fraction when no digestive enzymes and bile extract were added to the homogenate (data not shown). Boiling the lyophilised tomatoes for 15 min before digestion increased the micellarisation of lycopene, the carotenoid content in such preparations being $10 \cdot 3$ (SEM 0.9) $\mu \mathrm{g} / \mathrm{g}$ fresh weight.

As shown in Fig. 1, cells incorporated and/or associated lycopene in a linear manner. A time-dependent increase in lycopene content was observed in HT-29 cells treated with $100 \mathrm{ml}$ digestate $/ 1$ for $24 \mathrm{~h}$. The cellular carotenoid amount increased in a dose-dependent manner, being 0.10 (SEM 0.01 ), 0.30 (SEM 0.03) and 0.60 (SEM 0.06) ng/10 6 cells after the addition of 20,50 and $100 \mathrm{ml}$ digestate/l, respectively, for $24 \mathrm{~h}$. The digestion mixture itself, for example, proteolytic and lypolitic enzymes without tomato, diluted with culture medium and administered to the cells at the same concentration $(20-100 \mathrm{ml} / \mathrm{l})$ was not cytotoxic, as measured by the trypan blue exclusion method and caspase- 3 activation.

Tomato digestate inhibited the growth of HT-29 cells in a dose-dependent manner, as measured by direct cell counting (Fig. 2). This inhibition is shown at $24 \mathrm{~h}$ of incubation, but it was also found at $12 \mathrm{~h}$ (data not shown). Interestingly, the growth-inhibitory effects of tomato digestate were enhanced by boiling the tomatoes for $15 \mathrm{~min}$ before digestion. After the addition of tomato digestate at the concentration of $100 \mathrm{ml} / \mathrm{l}$ to culture medium for $24 \mathrm{~h}$, cell growth was inhibited by 36 (SEM 1.8) \% and 51 (SEM 2.8) \% using raw and heated tomato digestate, respectively.

To elucidate the mechanisms involved in the growth-inhibitory effects of tomatoes, we first examined whether the reduction in cell number by tomato digestate was associated with changes in cell cycle progression. As shown in Table 2, treatment with tomato digestate for $24 \mathrm{~h}$ resulted in a significant dose-dependent inhibition of cell cycle progression, manifested by the accumulation of cells in the G0/G1 phase and by a concomitant decrease in the percentage of cells in the $S$ phase and in the G2/M phase. Interestingly, the analysis of DNA histograms revealed the appearance of a pre-G1 peak (subdiploid DNA content), which is characteristic of apoptotic

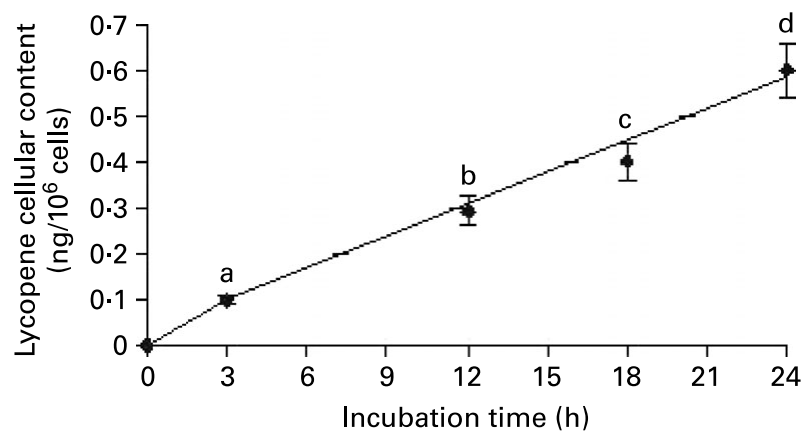

Fig. 1. Lycopene incorporation and/or association in HT-29 cells treated with tomato digestate $(100 \mathrm{ml} / \mathrm{l})$ for $24 \mathrm{~h}$. Data are mean values of three different experiments, with standard errors represented by vertical bars. ${ }^{a, b, c, d}$ Mean values with unlike letters were significantly different $(P<0.05)$ (Fisher's test). 


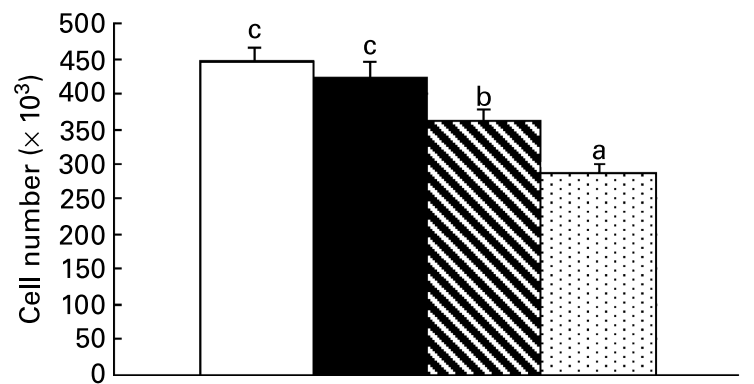

Fig. 2. Effects of varying tomato digestate concentrations on the growth of HT-29 cells treated for $24 \mathrm{~h}$. ( $\square)$, Control; $(\square)$, tomato digestate $(20 \mathrm{ml} / \mathrm{l})$; $(\mathbb{\mathbb { N }})$,

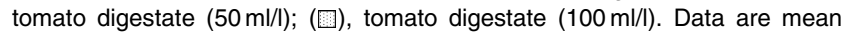
values of three different experiments, with standard errors represented by vertical bars. ${ }^{a, b, c}$ Mean values with unlike letters were significantly different $(P<0.05)$ (Fisher's test).

cell death, in HT-29 cells treated with tomato digestate. This value increased in a dose-dependent manner.

Apoptosis induction by tomato digestate was further studied by analysing the activation of caspase-3, one of the most important cell death executioners for apoptosis (Fig. 3). According to the results obtained by the analysis of the cell cycle, we found that a $24 \mathrm{~h}$ treatment with tomato digestate resulted in a strong increase in 7-amido-4-methylcoumarin fluorescence, indicative of the activation of caspase- 3 in HT-29 cells.

We also investigated possible mechanisms by which tomato digestate would interfere with cell cycle progression and apoptosis. Therefore, we evaluated the cellular content of cyclin $\mathrm{D} 1$, which is a regulatory protein during the G0/G1 phase of the cell cycle (Fig. 4 (A)). HT-29 treated with tomato digestate for $24 \mathrm{~h}$ showed a strong decrease in cyclin D1 expression compared with control cells. The effect was dose-dependent. This finding was consistent with the blockage of cell cycle progression in the G0/G1 phase. In contrast, the expression of p53 (Fig. 4 (B)), p21 and p27 (Fig. 4 (C)), three other proteins regulating the cell cycle, was not modified by a $24 \mathrm{~h}$ tomato digestate treatment.

To explore the effects of tomato digestate on apoptosis-regulating proteins, we examined the expression of $\mathrm{Bcl}-2$ and Bcl-xL, which suppress programmed cell death, and that of Bax, which promotes it, in HT-29 cells treated for $24 \mathrm{~h}$ (Fig. 5). Treatment with tomato digestate significantly reduced the expression of both Bcl-2 and Bcl-xL in a dose-dependent manner. In contrast, no significant changes in the expression of Bax were found in HT-29 cells following a $24 \mathrm{~h}$ treatment.
Similar effects of tomato digestate on cell growth (Fig. 6(A)), apoptosis (Fig. 6 (B)) and protein expression (Fig. 6(C)), including cyclin D1 and Bcl-2, were observed in HCT-116 cells, another human adenocarcinoma cell line (Fig. 6).

\section{Discussion}

In the present study, we digested tomatoes in vitro with a procedure that mimics the physiological process in intestinal cells and we have investigated the mechanisms involved in the growth-inhibitory effects of tomato products in colon cancer cells. In particular, we administered ripe tomatoes rich in lycopene to cultured cells after the in vitro digestion treatment. We then characterised lycopene accumulation into the treated cells and studied the antitumoural effects of the aqueous fraction digested, by focusing on some molecular pathways involved in cell proliferation and apoptosis. The present data show that tomato acts as a potent anticarcinogenic agent not only in prostate cancer cells as it has been reported in the literature, but also in colon cancer cells, by inhibiting cell cycle progression through a decrease in cyclin D1 expression and by inducing apoptosis through the modulation of Bcl-2 and Bcl$\mathrm{xL}$ proteins.

The in vitro digestion method has been used effectively for assessing the bioaccessibility and bioavailability of $\mathrm{Fe}^{26}$, amino acids ${ }^{27}$, cholesterol ${ }^{28}$, vitamin $\mathrm{B}_{6}{ }^{29}$ and, recently, carotenoids from baby-food meals ${ }^{20}$. It has been reported that the micellarisation of lutein exceeded that of $\alpha$-carotene, $\beta$-carotene and lycopene ${ }^{20,30}$. The poor ability of lycopene to form micelles with respect to that of lutein is probably due to the lower hydrophilicity of hydrocarbon carotenoids than oxycarotenoids as well as to their different subcellular locations and molecular interactions in plant foods. The location of carotenoids within the oil droplet which is formed during digestion is affected by its polarity and probably represents an important factor that influences the transfer to mixed micelles ${ }^{31}$. Moreover, hydrocarbon carotenoids, such as lycopene, are buried in the core of the oil droplet, whereas oxycarotenoids, such as lutein, reside near the surface ${ }^{31}$.

Although the micellarisation of lycopene has been reported to be extremely poor in baby-food meals after in vitro digestion $^{20}$, it should be noted that tomatoes possess a greater amount of lycopene than other foods ${ }^{16}$. Our finding that heating the samples allowed the release of higher amounts of lycopene from tomatoes is in agreement with the observation that the availability of lycopene during in vitro digestion is higher in tomato paste and in tomatoes cooked in the presence of oil.

Table 2. Effect of lyophilised tomato digestate on cell cycle distribution in HT-29 colon adenocarcinoma cells (Mean values with their standard errors of three different determinations)

\begin{tabular}{|c|c|c|c|c|c|c|c|c|}
\hline \multirow[b]{2}{*}{ Cells } & \multicolumn{2}{|c|}{ G0/G1 } & \multicolumn{2}{|c|}{$S$} & \multicolumn{2}{|c|}{$\mathrm{G} 2 / \mathrm{M}$} & \multicolumn{2}{|c|}{ Sub-G1 } \\
\hline & Mean & SEM & Mean & SEM & Mean & SEM & Mean & SEM \\
\hline Vehicle control-treated & $45 \cdot 0^{a}$ & $3 \cdot 0$ & $41 \cdot 0^{\mathrm{C}}$ & $2 \cdot 9$ & $12 \cdot 0^{\mathrm{c}}$ & $1 \cdot 1$ & $2 \cdot 0^{\mathrm{a}}$ & 0.2 \\
\hline Tomato digestate-treated $(20 \mathrm{ml} / \mathrm{l})$ & $44 \cdot 8^{\mathrm{a}}$ & $2 \cdot 9$ & $42 \cdot 5^{\mathrm{C}}$ & $3 \cdot 0$ & $10 \cdot 7^{c}$ & $1 \cdot 0$ & $2 \cdot 0^{\mathrm{a}}$ & 0.2 \\
\hline Tomato digestate-treated $(50 \mathrm{ml} / \mathrm{l})$ & $51 \cdot 3^{\mathrm{b}}$ & 3.5 & $34 \cdot 8^{\mathrm{b}}$ & 3.0 & $7 \cdot 0^{\mathrm{b}}$ & 0.5 & $6 \cdot 9^{\mathrm{b}}$ & 0.4 \\
\hline Tomato digestate-treated $(100 \mathrm{ml} / \mathrm{l})$ & $59 \cdot 5^{\mathrm{C}}$ & $4 \cdot 2$ & $26 \cdot 3^{a}$ & 2.5 & $4 \cdot 0^{\mathrm{a}}$ & 0.4 & $10 \cdot 2^{\mathrm{C}}$ & 0.7 \\
\hline
\end{tabular}

\footnotetext{
a,b,c Mean values within a column with unlike superscript letters were significantly different $(P<0.05)$ (Fisher's test).
} 


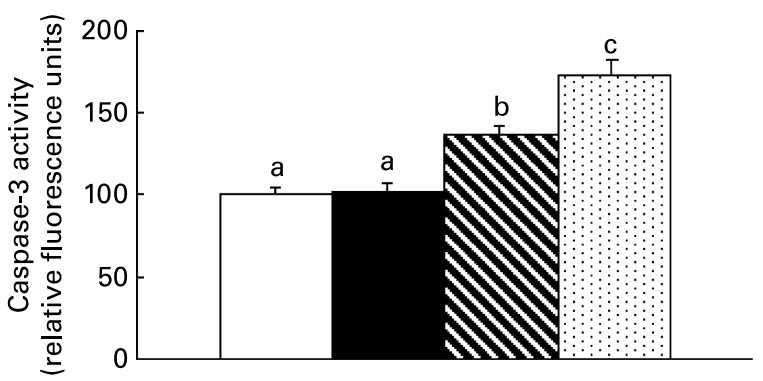

Fig. 3. Effects of varying tomato digestate concentrations on caspase-3 acti-

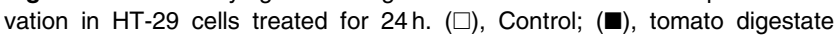
$(20 \mathrm{ml} / \mathrm{l}) ;(\mathbb{N})$, tomato digestate $(50 \mathrm{ml} / \mathrm{l}) ;(\mathbb{D})$, tomato digestate $(100 \mathrm{ml} / \mathrm{l})$. Data are mean values of three different experiments, with standard errors represented by vertical bars. ${ }^{a, b, c}$ Mean values with unlike letters were significantly different $(P<0.05)$ (Fisher's test).

The combination of bile salts and pancreatic enzymes is essential for the efficient micellarisation of lycopene from tomatoes $^{20}$.

The present data are in agreement with epidemiological evidence of a possible protective effect of lycopene against cancer $^{7}$, and with several clinical, animal, and tissue and cell-culture studies that have demonstrated through other approaches its anticarcinogenic potential ${ }^{17,32}$.

The different isomeric structures of lycopene and in general of carotenoids have been suggested to be important factors that influence their bioavailability and absorption ${ }^{33}$. Since also the composition and the structure of the food matrix

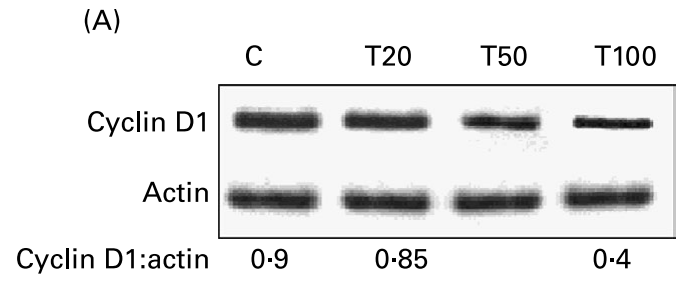

(B)

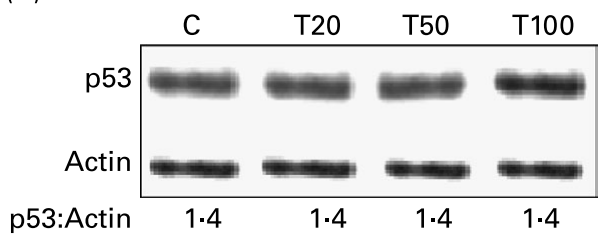

(C)

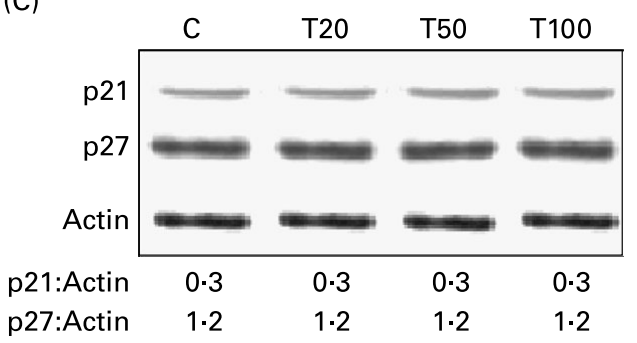

Fig. 4. Representative Western blot analyses of cyclin D1 (A), p53 (B) and p21 and p27 (C) expression in HT-29 cells treated with varying tomato digestate concentrations for $24 \mathrm{~h}$. C, control; T20, $20 \mathrm{ml}$ tomato digestate/; T50, $50 \mathrm{ml}$ tomato digestate/l; T100, $100 \mathrm{ml}$ tomato digestate/l. Values are expressed as protein:actin ratios.

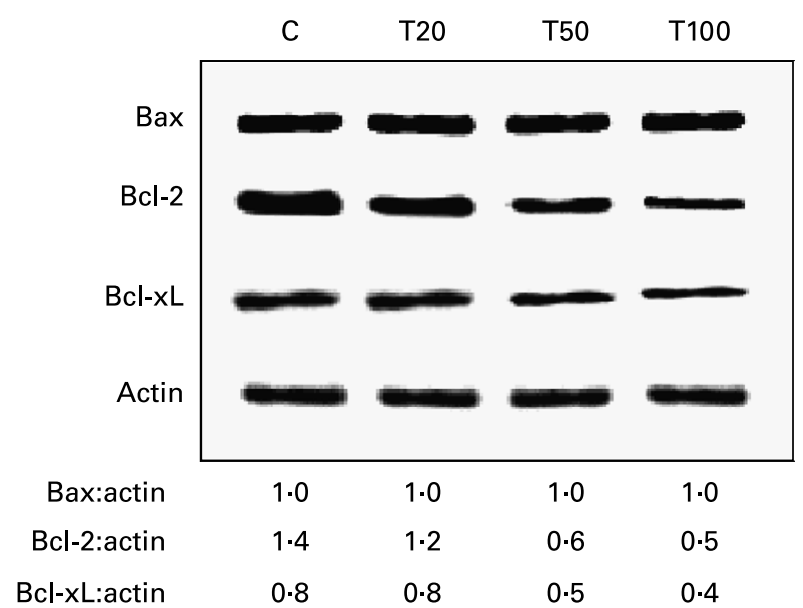

Fig. 5. Representative Western blot analyses of $\mathrm{Bax}, \mathrm{Bcl}-2$ and $\mathrm{Bcl}-\mathrm{xL}$ expression in HT-29 cells treated with varying tomato digestate concentrations for $24 \mathrm{~h}$. C, control; T20, $20 \mathrm{ml}$ tomato digestate/l; T50, $50 \mathrm{ml}$ tomato digestate/l; T100, $100 \mathrm{ml}$ tomato digestate/l. Values are expressed as protein:actin ratios.

have a strong impact on bioavailability of these molecules, in the present study we have chosen to utilise in vitro simulated digestion in order to release from tomatoes the carotenoid pool, focusing in particular on lycopene.

In the present paper, we reported that HT-29 cells were capable of accumulating lycopene from mixed micelles in a dose-dependent manner. Such an observation is not surprising in view of previous reports showing that another human colonic carcinoma cell line, Caco-2, accumulates carotenoids present in the aqueous or micellar fraction after in vitro digestion of the meal ${ }^{20}$. The present data demonstrate that ripe tomato digestates, very rich in lycopene, may act as potent growthinhibitory agents in vitro, confirming the observations of antitumoural effects of tomato products in vivo ${ }^{5,34}$. Growthinhibitory effects of purified lycopene have been reported in different tumour cell lines ${ }^{35}$, including prostate $^{36}$, mammary $^{37,38}$ and endometrial ${ }^{39}$ cancer cells and promyelocytic leukaemia cells ${ }^{40}$. However, it is important to underline that tomato digestates obtained by our experimental approach contain a complex mix of compounds besides lycopene, including other carotenoids such as phytoene and phytofluene, carotenoid metabolites and oxidative products, which better mimics the in vivo situation and that can be responsible for the growth-inhibitory effects observed.

The inhibition of HT-29 cell growth by tomato digestate was associated with a slowing of cell cycle progression at the G0/G1 phase. Such an effect seems to involve a down regulation of cyclin D1, which has been implicated in the control of this phase of the cell cycle. It is well known that cyclin $\mathrm{D} 1$ is an oncogene and it is over-expressed in several cancer cell lines ${ }^{41}$. It is interesting to note that lycopene alone has been reported to inhibit tumour cell growth by an arrest in cell cycle progression and a concomitant decrease in cyclin D1 expression. In fact, G0/G1 arrest was observed in lycopene-treated HL-60 cells ${ }^{40}$ and in RAT-1 immortalised fibroblasts $^{23}$. In MCF- $7^{37}$ and T47D breast cancer cells, as well as in ECC-1 endometrial cancer cells ${ }^{38}$, lycopene delayed G1-S transition by down regulating cyclin D1 and D3 protein expression, suggesting that the regulation of cell cycle 


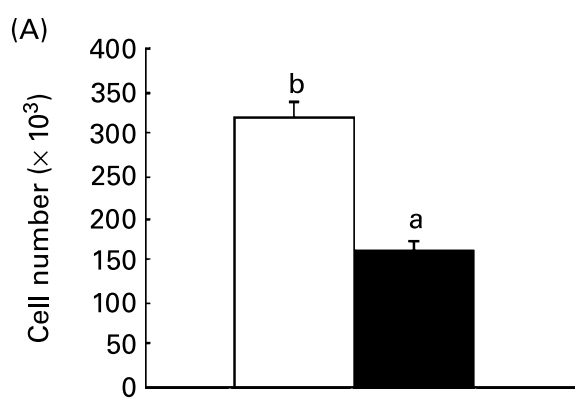

(B)
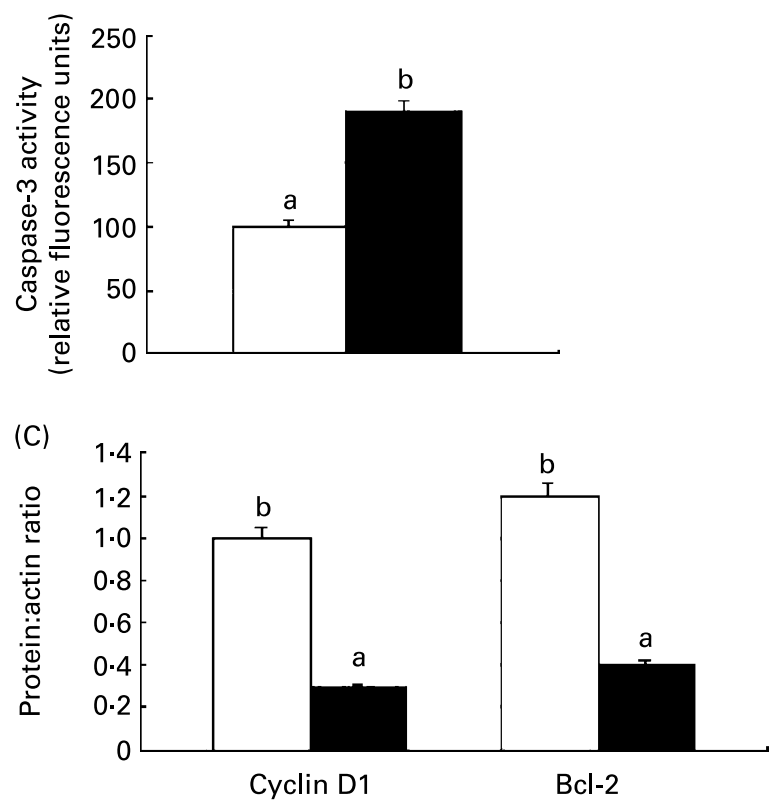

Fig. 6. Effects of tomato digestate on the growth (A), caspase-3 activation (B) and cyclin D1 and Bcl-2 expression (C) in HCT-116 cells treated with tomato digestate $(100 \mathrm{ml} / \mathrm{l} ; \mathbf{\square})$ for $24 \mathrm{~h}$. ( $\square)$, Control cells. Data are mean values of three different experiments, with standard errors represented by vertical bars. ${ }^{a, b}$ Mean values with unlike letters were significantly different $(P<0.05)$ (Fisher's test)

progression by lycopene involves a modulation of cyclins, cyclin-dependent kinases and cyclin-dependent kinase inhibitors. The present data on the modulation of cyclin D1 by tomato digestate confirm such findings and strongly support the hypothesis that lycopene could be directly implicated in the anticarcinogenic effects of tomatoes and tomato products.

Tomato digestate was able to induce apoptosis in colon cancer cells. There are few reports on apoptosis induction by lycopene and tomato products in cancer cells. Some authors ${ }^{42,43}$ did not find apoptosis induction by lycopene in different human prostate cancer cells even at very high lycopene concentrations. Lycopene was also apparently unable to induce apoptosis in HL-60 cells ${ }^{40}$ as well as in MCF-7 mammary cancer cells ${ }^{44}$. On the other hand, recent studies demonstrate that apoptosis can be detected by using lycopene in LNCaP human prostate cancer cells ${ }^{36,45}$. Oxidative metabolites of lycopene have been reported to act as potent apoptosis inducers ${ }^{46}$. In addition, tomato sauce increased the percentage of apoptotic cells in prostate carcinoma and, to a lower extent, also in prostatic hyperplasia $^{47}$, suggesting that the type of cells, the amount of lycopene administered, as well as tomato processing, may deeply influence the ability of the carotenoid to act as a pro-apoptotic agent.

Moreover, in the present study we have demonstrated that tomato digestate was able to decrease the expression of Bcl2 and Bcl-xL, two proteins belonging to the Bcl-2 family of proteins, both acting as inhibitors of programmed cell death. This effect was dose-dependent and strictly related to apoptosis induction. In contrast, the pro-apoptotic protein Bax was not affected by the treatment with tomato digestate.

In conclusion, the present data suggest that this in vitro tomato digestion procedure represents a useful and physiological approach to deliver tomato - and therefore lycopene and its related molecules - to cultured cells and to study molecular mechanisms underlying the anticarcinogenic properties of this vegetable. In particular, we demonstrated that tomato digestate is able to inhibit the growth of colon cancer cells by modulating the expression of regulators of the cell cycle and apoptosis.

\section{Acknowledgements}

The present study was supported by MIPAF, 'OGM in Agriculture', LYCOCARD, European Integrated Project no. 016213 and MIUR. We thank Dr Francesco Cellini (Metapontum Agrobios, Metaponto (MT), Italy) for providing lyophilised tomatoes.

\section{References}

1. Blum A, Monir M, Wirsansky I \& Ben-Arzi S (2005) The beneficial effects of tomatoes. Eur J Intern Med 16, 402-404.

2. Agarwal S \& Rao AV (2000) Tomato lycopene and its role in human health and chronic diseases. Can Med Assoc J 163, 739-744.

3. Willcox JK, Catignani GL \& Lazarus S (2003) Tomatoes and cardiovascular health. Crit Rev Food Sci Nutr 43, 1-18.

4. Rao AV (2002) Lycopene, tomatoes, and the prevention of coronary heart disease. Exp Biol Med (Maywood) 227, 908-913.

5. Giovannucci E (1999) Tomatoes, tomato-based products, lycopene, and cancer: review of the epidemiologic literature. J Natl Cancer Inst 91, 317-331.

6. Franceschi S, Bidoli E, La Vecchia C, Talamini R, D'Avanzo B \& Negri E (1994) Tomatoes and risk of digestive-tract cancers. Int $J$ Cancer 59, 181-184.

7. Giovannucci E, Ascherio A, Rimm EB, Stampfer MJ, Colditz GA \& Willett WC (1995) Intake of carotenoids and retinol in relation to risk of prostate cancer. J Natl Cancer Inst 87, $1767-1776$.

8. Giovannucci E, Rimm EB, Liu Y, Stampfer WC \& Willett J (2002) A prospective study of tomato products, lycopene, and prostate cancer risk. J Natl Cancer Inst 94, 391-398.

9. Burney PG, Comstock GW \& Morris JS (1989) Serologic precursors of cancer: serum micronutrients and the subsequent risk of pancreatic cancer. Am J Clin Nutr 49, 895-900.

10. Davies JN \& Hobson GE (1981) The constituents of tomato fruit - the influence of environment, nutrition, and genotype. Crit Rev Food Sci Nutr 15, 205-280.

11. Shi J \& Le Maguer M (2000) Lycopene in tomatoes: chemical and physical properties affected by food processing. Crit Rev Food Sci Nutr 40, 1-42. 
12. Campbell JK, Canene-Adams K, Lindshield BL, Boileau TW, Clinton SK \& Erdman JW Jr (2004) Tomato phytochemicals and prostate cancer risk. $J$ Nutr 134, 3486S-3492S.

13. Curl AL (1961) The xanthophylls of tomatoes. J Food Sci 26, 106-111.

14. Shi ML \& Le Maguer M (2000) Lycopene in tomatoes: chemical and physical properties affected by food processing. Crit Rev Biotechnol 20, 293-334.

15. Gann PH, Ma J, Giovannucci E, Willett W, Sacks FM, Hennekens CH \& Stampfer MJ (1999) Lower prostate cancer risk in men with elevated plasma lycopene levels: results of a prospective analysis. Cancer Res 59, 1225-1230.

16. Heber D \& Lu QY (2002) Overview of mechanisms of action of lycopene. Exp Biol Med (Maywood) 227, 920-923.

17. Levy J, Bosin E, Feldman B, Giat Y, Miinster A, Danilenko M \& Sharoni Y (1995) Lycopene is a more potent inhibitor of human cancer cell proliferation than either $\alpha$-carotene or $\beta$-carotene. Nutr Cancer 24, 257-266.

18. Xu X, Wang Y, Constantinou AI, Stacewicz-Sapuntzakis M, Bowen PE \& van Breemen RB (1999) Solubilization and stabilization of carotenoids using micelles: delivery of lycopene to cells in culture. Lipids 34, 1031-1036.

19. Palozza P, Serini S, Maggiano N, Angelini M, Boninsegna A, Di Nicuolo F, Ranelletti FO \& Calviello G (2002) Induction of cell cycle arrest and apoptosis in human colon adenocarcinoma cell lines by $\beta$-carotene through down-regulation of cyclin A and Bcl-2 family proteins. Carcinogenesis 23, 11-18.

20. Garrett DA, Failla ML \& Sarama RJ (1999) Development of an in vitro digestion method to assess carotenoid bioavailability from meals. J Agric Food Chem 47, 4301-4309.

21. Crissman HA \& Steinkamp JA (1973) Rapid, simultaneous measurement of DNA, protein, and cell volume in single cells from large mammalian cell populations. J Cell Biol 59, 766-771.

22. Palozza P, Serini S, Torsello A, Di Nicuolo F, Maggiano N, Ranelletti FO, Wolf FI \& Calviello G (2003) Mechanism of activation of caspase cascade during $\beta$-carotene-induced apoptosis in human tumor cells. Nutr Cancer 47, 76-87.

23. Palozza P, Sheriff A, Serini S, Boninsegna A, Maggiano N, Ranelletti FO, Calviello G \& Cittadini A (2005) Lycopene induces apoptosis in immortalized fibroblasts exposed to tobacco smoke condensate through arresting cell cycle and down-regulating cyclin D1, pAKT and pBad. Apoptosis 10, $1445-1456$.

24. Liu CS, Glahn RP \& Liu RH (2004) Assessment of carotenoid bioavailability of whole foods using a Caco- 2 cell culture model coupled with an in vitro digestion. J Agric Food Chem 52, 4330-4337.

25. Marletta L, Lucarini M, Ruggeri S \& Carnovale E (2000) Food composition databases in Italy: problems and perspectives. J Food Comp Anal 13, 611-618.

26. Etcheverry P, Wallingford JC, Miller DD \& Glahn RP (2005) The effect of calcium salts, ascorbic acid and peptic $\mathrm{pH}$ on calcium, zinc and iron bioavailabilities from fortified human milk using an in vitro digestion/Caco-2 cell model. Int J Vitam Nutr Res 75, 171-178.

27. Cave NA (1988) Bioavailability of amino acids in plant feedstuffs determined by in vitro digestion, chick growth assay, and true amino acid availability methods. Poult Sci 67, 78-87.

28. Fouad MF, Farrell PG, Marshall WD \& van de Voort FR (1991) In vitro model for lipase-catalyzed lipophile release from fats. J Agric Food Chem 39, 150-153.

29. Ekanayake A \& Nelson PE (1986) An in vitro method for estimating biologically available vitamin $\mathrm{B}_{6}$ in processed foods. Br J Nutr 55, 235-244.

30. Reboul E, Borel P, Mikail C, Abou L, Charbonnier M, CarisVeyrat C, Goupy P, Portugal H, Lairon D \& Amiot M-J
(2005) Enrichment of tomato paste with 6\% tomato peel increases lycopene and $\beta$-carotene bioavailability in men. J Nutr 135, 790-794.

31. Borel P, Grolier P, Armand M, Partier A, Lafont H, Lairon D \& Azais-Braesco V (1996) Carotenoids in biological emulsions: solubility, surface-to-core distribution, and release from lipid droplets. J Lipid Res 37, 250-261.

32. Kim L, Rao AV \& Rao LG (2002) Effects of lycopene on prostate LNCaP cancer cells in culture. J Med Food 5, 181-187.

33. Omoni AO \& Aluko RE (2005) The anti-carcinogenic and antiatherogenic effects of lycopene:a review. Trends Food Sci Technol 16, 344-350.

34. La Vecchia C (2002) Tomatoes, lycopene intake, and digestive tract and female hormone-related neoplasms. Exp Biol Med 227, $860-863$.

35. Bhuvaneswari V \& Nagini S (2005) Lycopene: a review of its potential as an anticancer agent. Curr Med Chem Anticancer Agents 5, 627-635.

36. Hwang ES \& Bowen PE (2005) Effects of lycopene and tomato paste extracts on DNA and lipid oxidation in LNCaP human prostate cancer cells. Biofactors 23, 97-105.

37. Ben-Dor A, Nahum A, Danilenko M, Giat Y, Stahl W, Martin HD, Emmerich T, Noy N, Levy J \& Sharoni Y (2001) Effects of acyclo-retinoic acid and lycopene on activation of the retinoic acid receptor and proliferation of mammary cancer cells. Arch Biochem Biophys 391, 295-302.

38. Hirsch K, Atzmon A, Danilenko M, Levy J \& Sharoni Y (2006) Lycopene and other carotenoids inhibit estrogenic activity of $17 \beta$-estradiol and genistein in cancer cells. Breast Cancer Res Treat, (Epublication ahead of print 19 October 2006).

39. Nahum A, Hirsch K, Danilenko M, Watts CK, Prall OW, Levy J \& Sharoni Y (2001) Lycopene inhibition of cell cycle progression in breast and endometrial cancer cells is associated with reduction in cyclin D levels and retention of p27(Kip1) in the cyclin E-cdk2 complexes. Oncogene 20, 3428-3436.

40. Amir H, Karas M, Giat J, Danilenko M, Levy R, Yermiahu T, Levy J \& Sharoni Y (1999) Lycopene and 1,25-dihydroxyvitamin $D_{3}$ cooperate in the inhibition of cell cycle progression and induction of differentiation in HL-60 leukemic cells. Nutr Cancer 33, 105-112.

41. Diehl JA (2002) Cycling to cancer with cyclin D1. Cancer Biol Ther 1, 226-231.

42. Hall AK (1996) Liarozole amplifies retinoid-induced apoptosis in human prostate cancer cells. Anticancer Drugs 7, 312-320.

43. Kotake-Nara E, Kushiro M, Zhang H, Sugawara T, Miyashita K \& Nagao A (2001) Carotenoids affect proliferation of human prostate cancer cells. J Nutr 131, 3303-3306.

44. Karas M, Amir H, Fishman D, Danilenko M, Segal S, Nahum A, Koifmann A, Giat Y, Levy J \& Sharoni Y (2000) Lycopene interferes with cell cycle progression and insulin-like growth factor I signaling in mammary cancer cells. Nutr Cancer 36, $101-111$.

45. Hantz HL, Young LF \& Martin KR (2005) Physiologically attainable concentrations of lycopene induce mitochondrial apoptosis in LNCaP human prostate cancer cells. Exp Biol Med (Maywood) 230, 171-179.

46. Nara E, Hayashi H, Kotake M, Miyashita K \& Nagao A (2001) Acyclic carotenoids and their oxidation mixtures inhibit the growth of HL-60 human promyelocytic leukemia cells. Nutr Cancer 39, 273-283.

47. Bowen P, Chen L, Stacewicz-Sapuntzakis M, Duncan C, Sharifi R, Ghosh L, Kim HS, Christov Tzelkov K \& van Breemen R (2002) Tomato sauce supplementation and prostate cancer: lycopene accumulation and modulation of biomarkers of carcinogenesis. Exp Biol Med (Maywood) 227, 886-893. 